Research Article

\title{
Patterns and practice of self-medication among children presenting with acute respiratory tract infection or diarrhoea
}

\author{
Shashi Kant Dhir ${ }^{1}$, Amit Jain ${ }^{2}$, Meenal Batta ${ }^{3}$, Gaganpreet Singh $^{4}$
}

\begin{abstract}
${ }^{1}$ Department of Paediatrics, Guru Gobind Singh Medical College, Faridkot, Punjab, India ${ }^{2}$ Department of Pharmacology, Guru Gobind Singh Medical College, Faridkot, Punjab, India, ${ }^{3}$ Department of Physiology, Guru Gobind Singh Medical College, Faridkot, Punjab, India, ${ }^{4}$ Department of Community Medicine, Guru Gobind Singh Medical College, Faridkot, Punjab, India
\end{abstract}

Received: 12 January 2016 Accepted: 23 January 2016

*Correspondence to: Dr. Shashi Kant Dhir, Email: drshashikantdhir @gmail.com

Copyright: () the author(s), publisher and licensee Medip Academy. This is an openaccess article distributed under the terms of the Creative Commons Attribution NonCommercial License, which permits unrestricted noncommercial use, distribution, and reproduction in any medium, provided the original work is properly cited.

\begin{abstract}
Background: Self-medication is quite prevalent in many parts of the world and has led to wastage of precious manpower and time due to many adverse consequences. As a result there is great burden on a country both financially as well as health point of view. The purpose of this study was to identify the pattern and practice of self-medication among children presenting with Acute Respiratory Tract Infection or Diarrhoea in a tertiary care hospital of northern India.

Methods: A single point cross sectional study was conducted in 500 parents accompanying the children in the Paediatrics out Patient Department (OPD) of a Medical College in Northern India. The tool used for the study was a predesigned questionnaire. The data was evaluated using descriptive statistical analysis.

Results: Out of 500 subjects 486 were found eligible for enrolment. Out of these eligible subjects, $308(63.3 \%)$ parents reported history of self-medication. $143(51.3 \%)$ male children were administered self-medication. This number was proportionately higher in females (79.7\%). The drug most commonly administered were non-steroidal anti-inflammatory drugs $(64.3 \%)$ followed by antibiotics and cough and cold preparations. The most common source of drug procurement was the left over drugs from previous treatment $(75.2 \%)$ followed by purchase from a medical store. Most common reason for self-medication was previous experience with the prescribed drugs $(76.6 \%)$.

Conclusions: The problem of self-medication of prescription only drugs is quite prevalent in this part of the country. As self-medication has its complications and adversities proper orientation and awareness of the population about selfmedication is of utmost importance for proper utilization of resources and manpower. Further the government agencies should ensure proper implementation and supervision of laws related to sale of 'Prescription only drugs'.
\end{abstract}

Keywords: Self-Medication, Children, Acute respiratory tract infection, Diarrhoea

\section{INTRODUCTION}

Self-medication is defined as consumption of drugs to cure a disease without consultation of a registered medical practitioner or repeated use of same drugs for repeated attack of similar symptoms. ${ }^{1}$ The practice of giving medicines without the prescription of qualified medical personnel may lead to harmful side effects including death. Neither the dosage nor the disease is same all the times. This practice is even more harmful in Pediatric population where the dosage varies directly with the weight of the child, a parameter which is bound to increase with time. Sub therapeutic dosage of any drug would lead to suboptimal effect from that medicine and it will lead to resistance of that drug. Another thing of concern is that when the patients taking these drugs do come to the qualified doctors, they do not enquire about the dosage of the drugs taken and change to higher antibiotics based upon the name of the molecules being consumed by the children. Resistance to the parent as well as next generation antibiotic will then increase because of this and it may potentiate the already 
mammoth problem of superbugs. Irrational use of medications in the form of self-medication is a common problem reported in the South East Asian countries. Many studies have shown that there is high prevalence of self-medication in these areas..$^{2-4}$ Not only the adults do take the medicines on their own there is evidence that there is increasing incidence of self-medication to their children also. ${ }^{5}$ However there is paucity of published data about the prevalence, causes of administration, and place of procurement of medicines for self-medication by parents to children in this region. This study was planned to generate and evaluate the data regarding pattern and practice of self-medication by the parents to their children in the northern region of India.

\section{METHODS}

\section{Study design}

This was a facility based one point cross sectional study done at Paediatrics out Patient Department (OPD) of a tertiary care hospital in Northern India.

\section{Subjects}

The parents accompanying the children presenting to the OPD with diagnosis of either acute upper respiratory tract infection or diarrhoea were recruited for this study. This diagnosis was taken from the prescription slip of the physician attending the patient. The study was conducted on 500 participants. The practices and pattern of selfmedication was studied only in subjects who had history of administration of self-medication.

\section{Exclusion criteria}

The subjects who refused to participate in the study were not enrolled. The subjects who submitted the incomplete questionnaire were also not included. The parents who were doctors by profession were excluded from the study to prevent potential bias.

\section{Methods}

Information on the study variables was collected using a pretested, structured questionnaire. The questionnaire had three parts consisting of socio-demographic details, practices and pattern of self-medication. The subjects were identified from the OPD and the objective of the study was explained to them. The age, sex, educational status, residential background, and socio economic status using modified Kuppuswami Socioeconomic Status Scale was noted. ${ }^{6}$

To evaluate the practices of self-medication the participants were asked about the history, frequency and drugs commonly used for self-medication, source of purchase of those medications. The frequency in parents who gave self-medication in more than $80 \%$ of the episodes of illness was labelled as most of the times, in $50 \%$ to $80 \%$ of episodes as frequent and in less than $50 \%$ of episodes as occasionally. Sources of information of drugs used, reasons for self-medication and time taken to seek first medical advice were noted to estimate the pattern of self-medication. Data was collected by the investigators, compiled and analysed using descriptive analysis using Microsoft Excel ${ }^{\mathrm{TM}}$ and statistical tests.

\section{Informed consent}

Written informed consent was taken from the subjects. They were provided with written and verbal information about the study. Confidentiality of the subjects was maintained.

\section{RESULTS}

In our study 500 subjects were enrolled during three months of the study period. The response rate was $97.2 \%$. Out of 500 participants 486 were found eligible for enrolment. The reasons for exclusion are given in Figure 1.

Table 1: Baseline variables $(\mathrm{N}=486)$.

\begin{tabular}{|c|c|c|c|}
\hline & & Value & Percentage \\
\hline \multirow{4}{*}{$\begin{array}{l}\text { Age of the } \\
\text { children }\end{array}$} & $<1$ year & 48 & 9.9 \\
\hline & 1 to 5 years & 286 & 58.9 \\
\hline & 5 to 10 years & 93 & 19.1 \\
\hline & 10 to 14 years & 59 & 12.1 \\
\hline \multirow{2}{*}{$\begin{array}{l}\text { Gender of } \\
\text { children }\end{array}$} & Males & 279 & 57.4 \\
\hline & Females & 207 & 42.6 \\
\hline \multirow{2}{*}{$\begin{array}{l}\text { Residential } \\
\text { Background }\end{array}$} & Urban & 143 & 29.4 \\
\hline & Rural & 343 & 70.6 \\
\hline \multirow{7}{*}{$\begin{array}{l}\text { Educational } \\
\text { Qualification } \\
\text { of parents }\end{array}$} & Illiterate & 29 & 5.9 \\
\hline & Primary School & 43 & 8.8 \\
\hline & $\begin{array}{l}\text { Middle School } \\
\text { Certificate }\end{array}$ & 69 & 14.2 \\
\hline & $\begin{array}{l}\text { High School } \\
\text { Certificate }\end{array}$ & 131 & 27.0 \\
\hline & $\begin{array}{l}\text { Senior } \\
\text { Secondary } \\
\text { Certificate }\end{array}$ & 105 & 21.6 \\
\hline & Graduation & 73 & 15.0 \\
\hline & $\begin{array}{l}\text { Post-graduation } \\
\text { and higher }\end{array}$ & 36 & 7.4 \\
\hline \multirow{3}{*}{$\begin{array}{l}\text { Socioeconom } \\
\text { ic Status }\end{array}$} & Upper & 72 & 14.8 \\
\hline & Middle & 191 & 39.3 \\
\hline & Lower & 223 & 45.9 \\
\hline
\end{tabular}




\section{Demographic profile}

Among 486 subjects who completed the questionnaire the age group of their children varied from 0-14 years, out of which $279(57.4 \%)$ were males and 207 (42.6\%) were females. Most respondents (70.6\%) were of rural background. Most of the study participants had high school or higher education. 45.9 percent were from lower socioeconomic status. The various baseline variables are listed in Table 1.

Table 2: Practices of self-medication ( $\mathrm{N}=308)$.

\begin{tabular}{|c|c|c|c|}
\hline & & Value & Percentage \\
\hline \multirow{2}{*}{$\begin{array}{l}\text { History of } \\
\text { Self- } \\
\text { medication }\end{array}$} & Yes & 308 & 63.3 \\
\hline & No & 178 & 36.7 \\
\hline \multirow{2}{*}{$\begin{array}{l}\text { Gender of } \\
\text { children } \\
\text { with history } \\
\text { of self- } \\
\text { medication }\end{array}$} & Males & 143 & 51.3 \\
\hline & Females & 165 & 79.7 \\
\hline \multirow{4}{*}{$\begin{array}{l}\text { Frequency } \\
\text { of Self } \\
\text { Medications }\end{array}$} & Never & 43 & 14.0 \\
\hline & Occasionally & 133 & 43.2 \\
\hline & Frequently & 87 & 28.2 \\
\hline & Most of the time & 45 & 14.6 \\
\hline \multirow{7}{*}{$\begin{array}{l}\text { Drugs } \\
\text { commonly } \\
\text { used }\end{array}$} & Antibiotics & 185 & 60.1 \\
\hline & NSAIDs & 198 & 64.3 \\
\hline & $\begin{array}{l}\text { Cough and cold } \\
\text { preparations }\end{array}$ & 162 & 52.6 \\
\hline & $\begin{array}{l}\text { Antidiarrhoeal } \\
\text { agents }\end{array}$ & 80 & 26.0 \\
\hline & $\begin{array}{l}\text { Oral Rehydration } \\
\text { Solution }\end{array}$ & 139 & 45.1 \\
\hline & Zinc & 123 & 39.9 \\
\hline & Any other & 59 & 19.1 \\
\hline \multirow{6}{*}{$\begin{array}{l}\text { Source of } \\
\text { purchase of } \\
\text { Medication }\end{array}$} & $\begin{array}{l}\text { Hospital } \\
\text { Pharmacy }\end{array}$ & 10 & 2.5 \\
\hline & Private Clinic & 15 & 3.7 \\
\hline & Medical Store & 212 & 52.0 \\
\hline & $\begin{array}{l}\text { Left over drugs } \\
\text { from previous } \\
\text { treatment }\end{array}$ & 232 & 75.3 \\
\hline & $\begin{array}{l}\text { Relatives and } \\
\text { Friends }\end{array}$ & 76 & 18.6 \\
\hline & Quacks & 103 & 33.4 \\
\hline
\end{tabular}

\section{Practice of self-medication}

Out of these eligible subjects, 308 (63.3\%) parents reported history of self-medication. 143 (51.3\%) male children were administered self-medication. This number was proportionately higher in females $(79.7 \%)$. The frequency of administration of self-medication in children was occasional $(43.2 \%)$ in most of the cases. The drug most commonly administered were non-steroidal antiinflammatory drugs (NSAIDs) followed by antibiotics and cough and cold preparations. The most common source of drug procurement was the left over drugs from previous treatment $(75.2 \%)$ followed by purchase from a medical store. The details of practice of self-medication being followed by the participants in this study are mentioned in Table 2.

Table 3: Pattern of self-medication $(\mathrm{N}=308)$.

\begin{tabular}{|c|c|c|c|}
\hline & & Value & Percentage \\
\hline \multirow{6}{*}{$\begin{array}{l}\text { Source of } \\
\text { information } \\
\text { of Drugs }\end{array}$} & $\begin{array}{l}\text { Previous } \\
\text { experience } \\
\text { without } \\
\text { prescription }\end{array}$ & 89 & 28.9 \\
\hline & Pharmacist & 83 & 26.9 \\
\hline & $\begin{array}{l}\text { Relatives and } \\
\text { Friends }\end{array}$ & 37 & 12.0 \\
\hline & $\begin{array}{l}\text { Advertisement in } \\
\text { Television or } \\
\text { Newspaper }\end{array}$ & 108 & 35.1 \\
\hline & $\begin{array}{l}\text { Previous } \\
\text { experience from } \\
\text { prescription }\end{array}$ & 196 & 63.6 \\
\hline & Others & 65 & 21.1 \\
\hline \multirow{10}{*}{$\begin{array}{l}\text { Reason for } \\
\text { self- } \\
\text { medication }\end{array}$} & Minor Problem & 178 & 57.8 \\
\hline & $\begin{array}{l}\text { Previous } \\
\text { Experience from } \\
\text { similar disease }\end{array}$ & 236 & 76.6 \\
\hline & Time constraints & 119 & 38.7 \\
\hline & $\begin{array}{l}\text { Advice from } \\
\text { Friend }\end{array}$ & 22 & 7.1 \\
\hline & $\begin{array}{l}\text { Financial } \\
\text { Constraints }\end{array}$ & 109 & 36.1 \\
\hline & $\begin{array}{l}\text { Urgency of } \\
\text { Problem }\end{array}$ & 26 & 8.4 \\
\hline & $\begin{array}{l}\text { Uncooperative } \\
\text { attitude of } \\
\text { clinical staff }\end{array}$ & 2 & 0.6 \\
\hline & $\begin{array}{l}\text { Unavailability of } \\
\text { Transport }\end{array}$ & 56 & 18.2 \\
\hline & Others & 103 & 33.4 \\
\hline & $\begin{array}{l}\text { Self-belief in } \\
\text { recovery }\end{array}$ & 126 & 40.9 \\
\hline \multirow{3}{*}{$\begin{array}{l}\text { Time taken } \\
\text { to seek first } \\
\text { medical } \\
\text { advice after } \\
\text { illness }\end{array}$} & $<3$ days & 37 & 12.0 \\
\hline & 3-5 days & 174 & 56.5 \\
\hline & $>5$ days & 97 & 31.5 \\
\hline
\end{tabular}




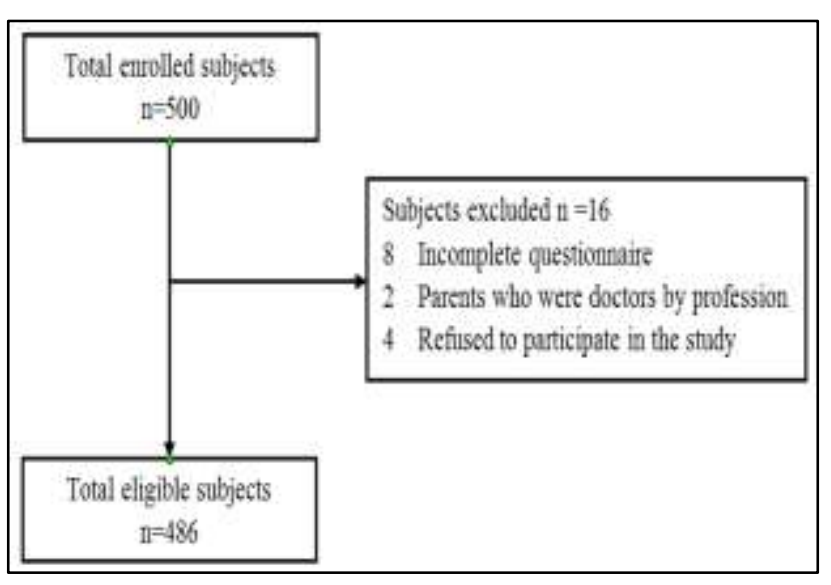

Figure 1: Trial flow.

\section{Pattern of self-medication}

The most common source of information of drugs was found to be previous experience with already prescribed drugs the drug for similar symptoms $(63.6 \%)$ followed by advertisement in television or newspaper. Most common reason for self-medication was previous experience $(76.6 \%)$. Time taken to seek first medical consultation after self-medication is three to five days in $56.5 \%$ participants. The details of pattern of self-medication by the participants are being tabulated in Table 3.

\section{DISCUSSION}

In this study pattern and practice of self-medication among children presenting in the paediatric OPD was assessed with the help of a predesigned questionnaire to know the extent of self-medication in paediatric population. In our study approximately two third of participants reported administrating self-medication to their children. This is in agreement with studies which also found that most of the mothers self-medicated their children. $^{7-10}$ More than half of the male children were administered self-medication. The proportion of female children being self-medicated was even much higher, almost eight out of ten. This is in coherence with another study which showed that fewer males were selfmedicated as compared to females. ${ }^{11}$ This could be due to the potential gender bias prevalent in the country and decreased tendency of the parents to seek medical advice for the females. ${ }^{12}$

The most common source of information of drugs was found to be previous experience with the prescribed medication for similar symptoms. This is in contrast to the study showing the commonest source of information as drug stores with almost two out of five persons gaining information from them. ${ }^{7}$ The reason for this difference might be the difference in socioeconomic status, educational qualification of the community and easy availability of the drugs from the drug stores. In another study in Italy, consultation with paediatrician was found to be major source of information. ${ }^{8}$ This difference in opinion might be attributed to the difference in awareness and availability \& utilisation of health resources. Most common reason for self-medication in our study was previous experience with similar disease. This is in contradiction to a study which shows that financial constraints amount to most of the parents opting for selfmedication. ${ }^{7}$ This again can be attributed to difference in socioeconomic status of the society. In our study lack of time is also a contributing factor to parents resorting to self-medication which is in conjunction with the study showing many mothers opting for self-medication due to lack of time and ease of self-administration. ${ }^{13}$ The frequency of administration of self-medication in children was occasional in most of the cases. The drug most commonly administered were NSAIDs followed by antibiotics and cough and cold preparations. This is also supported by a few of the studies showing use of NSAIDs as a foremost drug for self-administration. $7,14,15$

The most common source of drug procurement found in this study was the left over drugs from previous treatment followed by purchase from a medical store. This is in opposition to a study showing drug stores as the most important source of drugs without a valid prescription whereas left over medication amounted for very less number of participants. ${ }^{16}$ The reason for this difference might be attributed to more awareness and educational status of the community. Time taken to seek first medical consultation after self-medication was between three to five days in almost half of the subjects. This can be taken as a positive pattern because of the fact that parents are concerned about the health of their children and do not take any chances by delaying the consultation of a physician. To the best of our knowledge no previous study has given this data.

\section{CONCLUSION}

This study concludes that there is high prevalence of selfmedication even in children in this part of the country. There is need for organization of community based educational programmes and awareness campaigns to enlighten the community with hazards of self-medication and to make them aware of the importance of consultation with a registered medical practitioner even if the magnitude of the disease is not high as per their belief. Further there can be suggestions for the government for strict compliance of its rules and regulations in sale of medications without prescriptions.

\section{Limitations of the study}

This study has several limitations even after having high rate of response to the questionnaire. This study was a 
questionnaire based study and the process of data collection was dependent on the recollection memory of the subjects there can be recall bias. This study was conducted at a single centre which can be a limitation to this study. The data is subjective and the difference in education level was not taken into consideration. Number of children, source of earning of the family, status of health of family, educational background of the subjects was not considered in the study which could be decisive in further evaluation of the study.

\section{Future prospects}

Similar studies can be planned at more than one location to improve the quality and quantity of the data collection. Further the stratification of the education level of the community can be done thereby improving the strength of the data generated. All the other parameters which were not considered in this study could be studied and evaluated.

Funding: No funding sources

Conflict of interest: None declared

Ethical approval: The study was approved by the Institutional Ethics Committee

\section{REFERENCES}

1. WHO: Guidelines for the regulatory assessment of Medicinal Products for use in self-medication. WHO/EDM/QSM/00.1. Geneva, 2000.

2. Badiger S, Kundapur R, Jain A, Kumar A, Pattanshetty S, Thakolkaran N, et al. Self-medication patterns among medical students in South India. Australas Med J. 2012;5(4):217-20.

3. Hussain A, Khanum A. Self medication among university students of Islamabad, Pakistan - a preliminary study. South Med Rev. 2008;1(1):14-6.

4. Alam N, Saffoon N, Uddin R. Self-medication among medical and pharmacy students in Bangladesh. BMC Res Notes. 2015;8(1):763.

5. Office of population census and surveys. The general household survey. Practitoner. 1983; 227:1609-915.

6. Bairwa M, Rajput M, Sachdeva S. Modified Kuppuswamy's Socioeconomic Scale: Social Researcher Should Include Updated Income Criteria, 2012. Indian J Community Med Off Publ Indian Assoc Prev Soc Med. 2013;38(3):185.

7. Tibdewal S, Gupta M. Mother's use of medication in their children of preschool age. Indian J Public Health. 2005;49(1):27-9.
8. Pileggi C, Mascaro V, Bianco A, Pavia M. Over-theCounter Drugs and Complementary Medications Use among Children in Southern Italy. BioMed Res Int. 2015;2015:413912.

9. Bella H, Ai-Freihi H, El-Mousan M, Danso KT, Sohaibani M, Khazindar MS. Knowledge, Attitudes and Practices related to Diarrhoea in Eastern Province, Saudi Arabia. J Fam Community Med. 1994;1(1):40-4.

10. Jensen JF, Gottschau M, Siersma VD, Graungaard $\mathrm{AH}$, Holstein BE, Knudsen LE. Association of maternal self-medication and over-the-counter analgesics for children. Pediatrics. 2014;133(2):e291-8.

11. Mohanna M. Self-medication with Antibiotic in Children in Sana'a City, Yemen. Oman Med J. 2010;25(1):41-3.

12. Arokiasamy P, Pradhan J. Gender bias against female children in India: Regional differences and their implications for MDGs. Paper Presented at: The 2006 Annual Meeting of the Population Association of America; 2006 March 30 - April 1; Los Angeles, California. p22.

13. Le TH, Ottosson E, Nguyen TKC, Kim BG, Allebeck P. Drug use and self-medication among children with respiratory illness or diarrhea in a rural district in Vietnam: a qualitative study. J Multidiscip Healthc. 2011;4:329-36.

14. Anderson C, Rolfe P, Brennan-Hunter A. Administration of over-the-counter medication to children at home--a survey of parents from community health centers. J Community Health Nurs. 2013;30(3):143-54.

15. Nydert P, Kimland E, Kull I, Lindemalm S. Overthe-counter drug use--estimations within the Swedish paediatric population. Eur J Pediatr. 2011;170(5):583-8.

16. Pavydè E, Veikutis V, Mačiulienè A, Mačiulis V, Petrikonis K, Stankevičius E. Public Knowledge, Beliefs and Behavior on Antibiotic Use and SelfMedication in Lithuania. Int $\mathbf{J}$ Environ Res Public Health. 2015;12(6):7002-16.

Cite this article as: Dhir SK, Jain A, Batta M, Singh G. Patterns and practice of self-medication among children presenting with acute respiratory tract infection or diarrhoea. Int J Basic Clin Pharmacol 2016;5:33-7. 